\title{
Digital Sphygmomanometer Based on Arduino Using TFT LCD Display
}

\author{
Yasmine Winda Kusumaningtyas ${ }^{\#}$, Tri Bowo Indrato, M.Prastawa Asalim T.P., Bedjo Utomo \\ Department of Electromedical Engineering Poltekkes Kemenkes, Surabaya \\ Jl. Pucang Jajar Timur No. 10, Surabaya, 60245, Indonesia \\ \#yasmine.winda97@gmail.com, tribowo.tem81@gmail.com,prast77@poltekkesdepkes-sby.ac.id, \\ Bedjoutomo123@gmail.com
}

\begin{abstract}
Sphygmomanometer is a human blood pressure measuring device which has several types such as mercury, digital, and aneroid. At this time, mercury Sphygmomanometer is not allowed to be used anymore considering the side effects of mercury which can harm the skin and even respiration. This study helps to reduce the use of mercury type Sphygmomanometer. The researchers make Arduino TFT LCD display based Sphygmomanometer so that the use of mercury can be reduced and make it easier for users to process measurement. The researchers used the oscillometry method in making the device to calculate the systolic and diastolic pressure. The result of blood pressure measurement has a systolic error rate of $0,08 \%$ and a diastolic error rate $0,09 \%$.
\end{abstract}

\section{Keywords — Digital Sphygmomanometer, Arduino, TFT LCD, Oscillometri Method}

\section{INTRODUCTION}

Humans body conditions can be known by conducting vital sign examinations. Vital signs are body parameters to determine the physiological function of vital organs in the human body which are blood pressure, respiratory rate, body temperature and pulse. One of common vital sign examinations is blood pressure examination. [1]

Blood pressure is the pressure found in the arteries (arteries). The heart beats 60 to 70 times in 1 minute in a rest condition which is sitting or lying down when the heart beats the blood is pumped which then goes through arteries. The says of systolic pressure when the heart pumps blood and when the heart relaxes, the blood pressure decreases which is called diastolic pressure. Writing on systolic blood pressure per diastolic, for instance: 120/80 [2]. Hypertension and hypotension are two disorders which are caused by blood pressure. Hypertension means high blood pressure while hypotension means low blood pressure. Hypertension sufferers have several factors which influence them such as age, sex, and ethnicity, genetic factors, and environmental factors. [3]. These factors can lead to chronic internal diseases if blood pressure is low or high. However, the risk can be anticipated by doing a blood pressure examination regularly using blood pressure gauge (tensimeter).

Tensimeter is a health sector tool which is used to measure blood pressure. Nowadays, tensimeter is growing in the medical world. Starting from mercury tensimeter to digital tensimeter [4]. However, mercury tensimeter is currently not allowed by the government because the use of mercury is very dangerous for activities and can give a negative impact on the environment. This is stated in the Law of the Republic of Indonesia Number 11 of 2017 concerning Endorsement of the
Minamata Convention On Mercury [5]. Meanwhile, the digital tensimeter is developing into a portable digital tensimeter which can be carried everywhere.

Ruri Hartika Zain et al. conducted a study entitled Design of Blood Pressure and Body Temperature Based on ATmega8535 Microcontroller Supported by C and Delphi Programming Languages in 2012. This research was motivated to measure blood pressure digitally because the use of measuring instruments, which were still mercury-based, was susceptible to reading errors and hearing errors when finding systole and diastole. This study utilizes MPX5050DP sensor, with Code Vision Avr processing and display on PC using the Delphi program. The weakness of this study is the lack of precision and sensitivity of the sensors used.

In 2015, Parlindungan Fernando Nainggolan et al. conducted a study entitled Designing a System for Monitoring and Sending Blood Pressure Data on Android Mobile Platforms Using Bluetooth Connections, this research was inspired to measure blood pressure digitally because the use of heavy metals has been very dangerous to the environment. This study uses the MPX5100DP sensor with Atmega32 which will be displayed on android using a shipping model via Bluetooth HC-05. The weakness of the tool as a whole is that the average error of measurement value was obtained systematically with an average measurement error of blood pressure measuring devices for systolic measurements of $3.687 \%$ and for diastolic measurements of $4.768 \%$. The error obtained based on testing of standard tensimeter using Korotkoff blood pressure measurements.

Furthermore, Tri Rangga Rizqi conducted a study entitled, Digital Tensimeter Based on Atmega8535 Microcontroller in 2015. This research was motivated to minimize errors caused 
by dirty mercury, dirty mercury tubes, and the presence of bubbles in mercury tubes. This research uses MPX5100DP sensor, uses Atmega8535 with LCD display and LED bar as a determinant of bulb pressure. The weakness of this study is the high error value caused by inconstantly regulated air exhaust and poor program to minimize error values. The tool made by the researcher still used the mercury system in determining the value of the systole and the patient's diastole value.

Then, Ratnadewi, et al. Conducted a study entitled, Automatic Blood Pressure Detector Using Arduino to Measure Blood Pressure in Indonesian People Age 19-27 Years Old in 2018. This study was motivated to anticipate the disease of hypertension which is often experienced at the age of 19-27 years. This research uses MPX5700AP sensor, using ArduinoMega 2560 with LCD display. The accuracy of the calibration measurements with the device is $99.47 \%-99.82 \%$. Retrieving data on respondents, this study has different results between before and after the calibration. This study measured three conditions, namely comparison with standardized tools, the study before calibration and the study condition which was calibrated. This study did not use amplifier circuits or filters after sensors, the researchers only used relays as motor drivers and valve drivers. The weakness of this tool when it has not been calibrated is that the difference in value with the end result of the tool after calibration is very high, the value lies in the systole around $5 \mathrm{mmHg}$ while the diastole is $4 \mathrm{mmHg}$.

Based on the identification of problems above, the researchers intend to make Arduino TFT Lcd Display Based Digital Sphygmomanometer. This research will measure systole and diastole automatically using Arduino which will be displayed on the LCD.

\section{MATERIALS AND METHODS}

\section{A. Experimental Setup}

This study used 5 normal subjects with the criteria of adulthood. Subjects were taken randomly and data collection was repeated 3 times.

\section{1) Materials and Tool}

This research uses handcuffs. Handcuffs are placed on the left arm in humans. An instrumentation amplifier is built based on LM324 OP-AMP. The Arduino Mega microcontroller is used to process analog data into digital data displayed to the TFT LCD.

\section{2) Experiment}

In this study, after the design is complete, the module will be tested using a digital sphygmomanometer. Digital modules and sphygmomanometers will be used by humans on the right and left arm to compare the results.

\section{B. The Diagram Block}

When the battery is installed, the battery supplies voltage to the circuits in the device so that the device will always be active. The patient uses the cuff which is already available, the cuff puts air pressure on the pressure sensor. The pressure sensor receives and reads the results of the air pressure from the cuff. The pressure sensor output is sent and received by the circuit of instrumentation amplifiers whose results will be sent and received by the filter circuit. In this filter circuit, it only takes some data according to the filter function used. The output filter enters the amplifier to be amplified. So, it can be read and accepted by the microcontroller. The microcontroller processes it into digital and displays it on the LCD. In addition, the microcontroller also instructs motor drivers and solenoid drivers to work or stop. The motor driver works to turn on the pump motor to inflate the cuff while the solenoid driver turns on the solenoid valve.

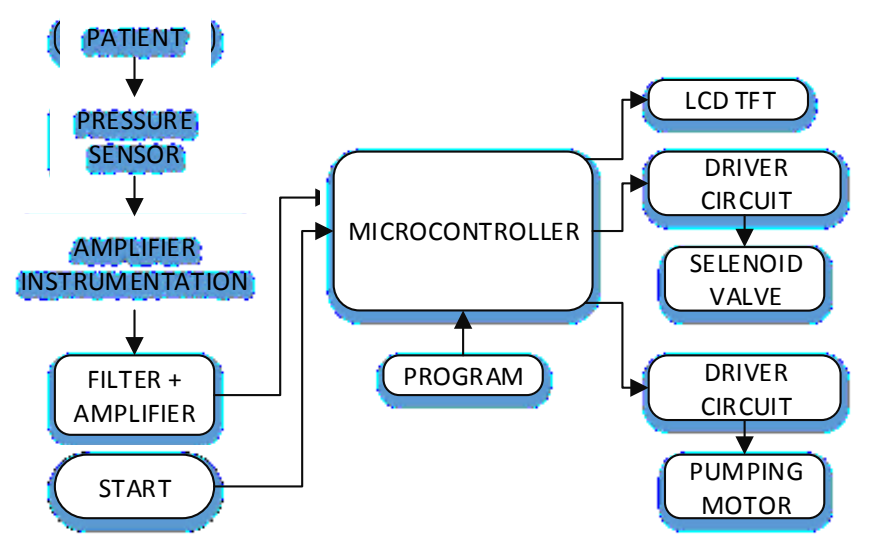

Fig. 1. The Diagram Block

C. The Flowchart
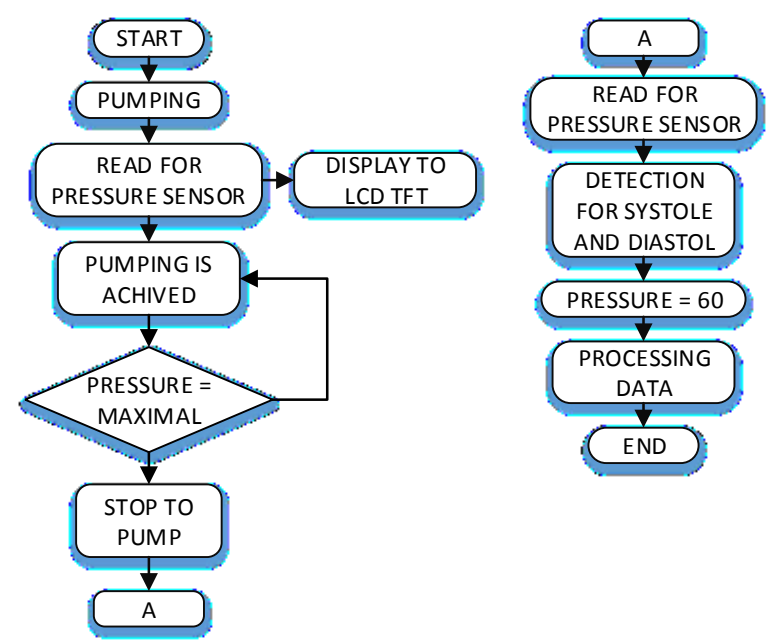

Fig. 2. The Process Flowchart

The Arduino program is built on a flow diagram as shown in Figure. 2. After the Arduino initialization, the program asks whether the pressure is maximal. if the pressure is maximized, the driver valve circuit will turn on and the motor driver circuit will turn off. Then the results of systole and diastole will be displayed on the TFT LCD.

\section{The Analog Circuit}

An important part of this development is the analog circuit that illustrates in Fig. 3 (buffer), Fig. 4 (different amplifier), 
and Figure. 5 (filter). This circuit is used before entering Arduino.

\section{1) Buffer}

This buffer circuit produces an output voltage equal to the input voltage. This circuit is a current amplifier without any voltage gain.

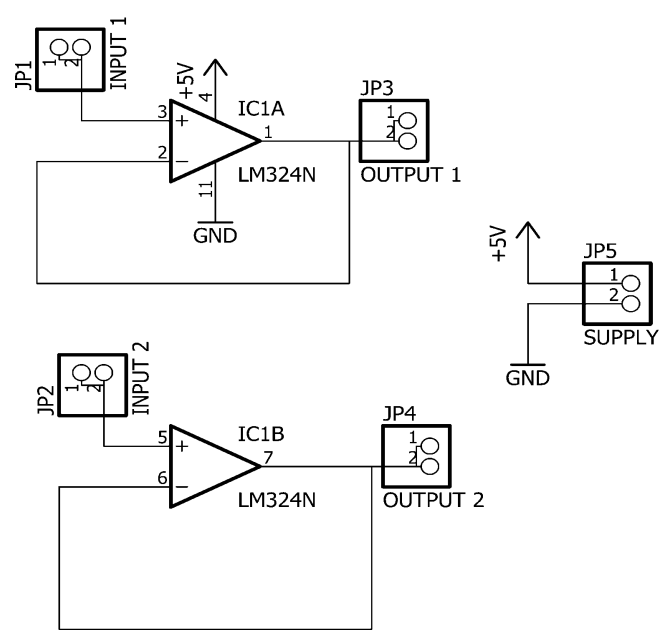

Fig. 3. Buffer

\section{2) Different Amplifier}

This circuit sums up the results of the previous circuit, namely the buffer circuit. The sum result will then be strengthened using multiturn. In this circuit, if measured using a Multimeter produces $0.32 \mathrm{~V}$ before being pressured.

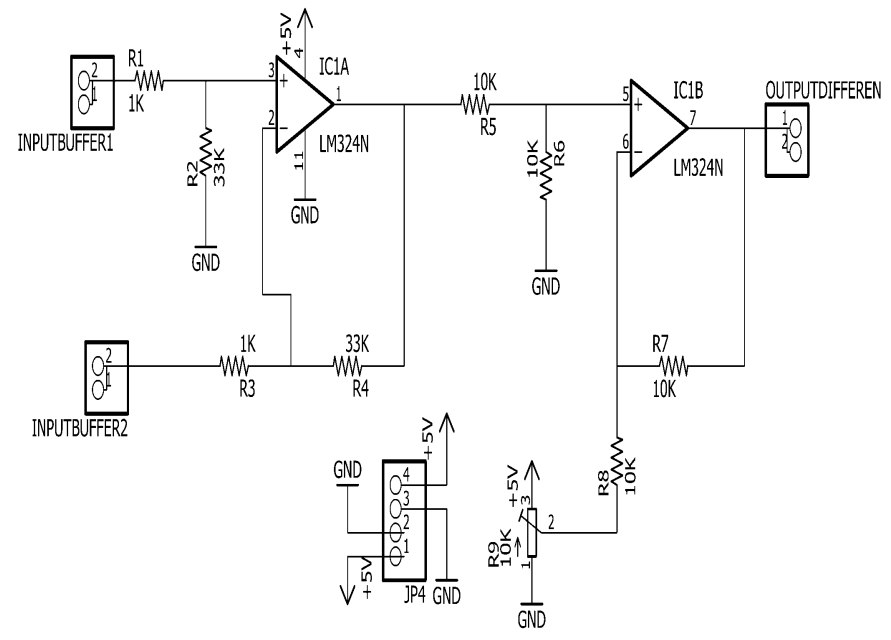

Fig. 4. Different Amplifier

\section{3) Filter}

The filter circuit is activated to get a signal from handcuffs using a pressure sensor. This circuit, use the $1 \mathrm{~Hz}$ cut-off frequency. If below the cut-off frequency of $1 \mathrm{~Hz}$ there is usually moved from the patient or handcuffs. This circuit is measured using an avometer will issue a $2.5 \mathrm{~V}$ voltage in any position without pressure. Then the output of the circuit filter will be connected to the Arduino Mega as input. Analog data will be converted into digital data while on Mega Arduino.

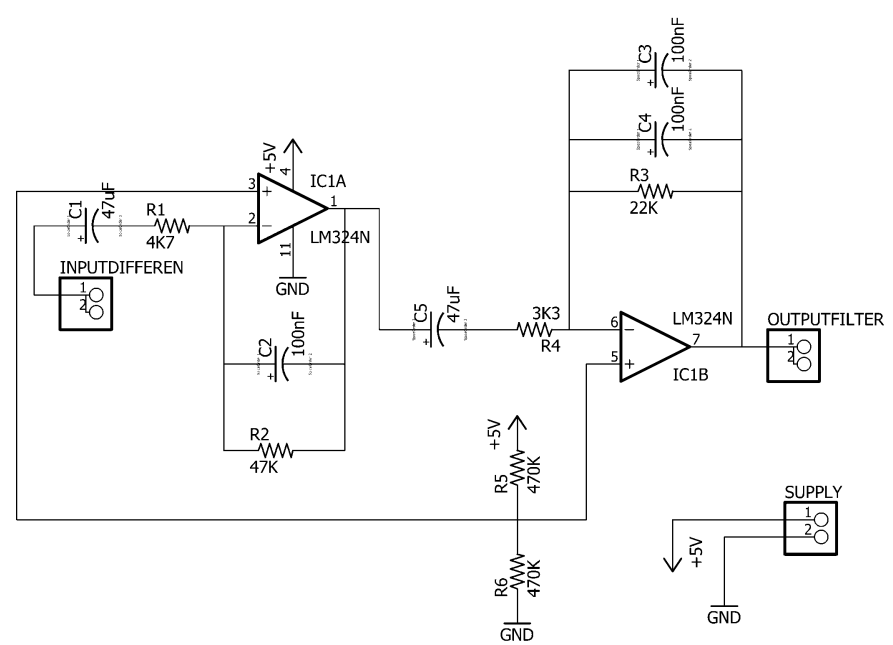

Fig. 5. Filter

\section{RESULTS}

In this study, the Module has been compared with a digital sphygmomanometer from the human body. Modules have also been measured at the test points on the circuit.

TABLE I. TEST POINT MEASUREMENT

\begin{tabular}{ccc}
\hline No & $\begin{array}{c}\text { Pressure } \\
(\mathrm{mmHg})\end{array}$ & $\begin{array}{c}\text { Mean } \\
(\mathrm{V})\end{array}$ \\
\hline 1 & 0 & 0.3 \\
\hline 2 & 20 & 0.4 \\
\hline 3 & 40 & 0.59 \\
\hline 4 & 60 & 0.76 \\
\hline 5 & 80 & 0.94 \\
\hline 6 & 100 & 1.13 \\
\hline 7 & 120 & 1.32 \\
\hline 8 & 140 & 1.5 \\
\hline 9 & 160 & 1.69 \\
\hline 10 & 180 & 1.89 \\
\hline
\end{tabular}

Measurement was conducted six times in TP1 which was the output of the amplifier at the time when there was no pressure given and when some pressures were given. Based on the measurement, the average result shows that there is $0.3 \mathrm{~V}$ voltage at 0 pressure, $0.4 \mathrm{~V}$ voltage at 20 pressure, $0.59 \mathrm{~V}$ voltage at 40 pressure, $0.76 \mathrm{~V}$ voltage at 60 pressure, $0.94 \mathrm{~V}$ voltage at 80 pressure, $1.13 \mathrm{~V}$ voltage at 100 pressure, $1.32 \mathrm{~V}$ voltage at 120 pressure, $1.5 \mathrm{~V}$ voltage at 140 pressure, $1.69 \mathrm{~V}$ voltage at 160 pressure, and $1.89 \mathrm{~V}$ voltage at 180 pressure.

Based on the result of data collection on 5 relaxed sitting respondents with 3 time measurements each using module and digital blood pressure gauge (sphygmomanometer) as a 
comparison to see systolic blood pressure and diastolic blood pressure, therefore, it is attained that the biggest systolic error value $0.08 \%$ and the biggest diastolic error value is $0.09 \%$. Whereas the smallest systolic error value is $0.01 \%$ and the smallest diastolic error value is $0.01 \%$.

\section{1) The Listing Program for Basic initialization}

Initialization here serves as the initial address for entering programs on Arduino. The minimum system uses Arduino Mega with a screen display using a TFT LCD. The TFT LCD.

\begin{tabular}{|c|c|c|c|}
\hline \multirow{2}{*}{$\begin{array}{c}\text { Respon } \\
\text { dent }\end{array}$} & \multirow[t]{2}{*}{ Instrument } & $\begin{array}{c}\text { Systollic } \\
\text { Error }\end{array}$ & $\begin{array}{c}\text { Diastolic } \\
\text { Error }\end{array}$ \\
\hline & & $\%$ & $\%$ \\
\hline \multirow{2}{*}{1} & Module & \multirow{2}{*}{$0.03 \%$} & \multirow{2}{*}{$0.01 \%$} \\
\hline & Sphygmomanometer & & \\
\hline \multirow{2}{*}{2} & Module & \multirow{2}{*}{$0.08 \%$} & \multirow{2}{*}{$0.05 \%$} \\
\hline & Sphygmomanometer & & \\
\hline \multirow{2}{*}{3} & Module & \multirow{2}{*}{$0.01 \%$} & \multirow{2}{*}{$0.02 \%$} \\
\hline & Sphygmomanometer & & \\
\hline \multirow{2}{*}{4} & Module & \multirow{2}{*}{$0.01 \%$} & \multirow{2}{*}{$0.06 \%$} \\
\hline & Sphygmomanometer & & \\
\hline \multirow{2}{*}{5} & Module & \multirow{2}{*}{$0.02 \%$} & \multirow{2}{*}{$0.09 \%$} \\
\hline & Sphygmomanometer & & \\
\hline
\end{tabular}

TABLE II. Systole AND Diastolic MEASUREMENT

displays the measurement results in the form of numbers. Where the tensimeter is initialized by pin 8 as a button to start the tensimeter measurement. The process of measuring tensimeter by measuring blood pressure when the start button is pressed will feed the pump will work where pin 10 is initialized as a pump that automatically pumps and the valve is closed automatically, pin 9 is initialized as a valve, otherwise the pressure is reached, the pump will slowly land down and open the valve.

2) The Listing Program for Motor driver circuit and valve driver circuit
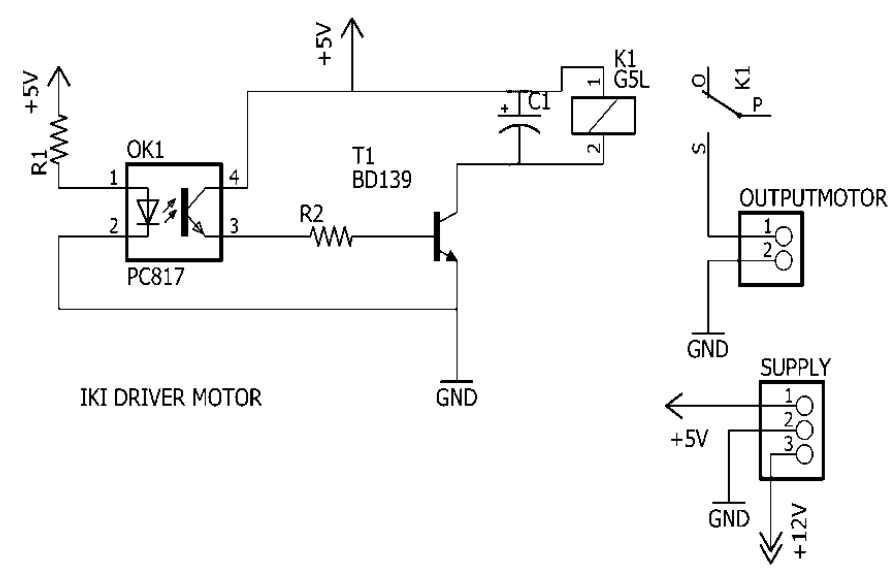

Fig. 6. Motor driver circuit and valve driver circuit

In standby, the pump is still off and the valve is open. Arduino output is in the form of a high / $4.55 \mathrm{Vdc}$ signal to the base of the BD139 transistor which is of type NPN, 0V from Arduino so that the transistor is saturated. When the start button is pressed then the transistor saturation then a voltage of $5.1 \mathrm{Vdc}$ which will ignite the relay to provide voltage to the motor to work slowly into the cuff and the solenoid valve will be closed through giving instructions from Arduino through pin 10 and pin 9 by giving input low (0). After reaching maximum pressure, Arduino will give high instructions to pin 9 so that pin 10 stops working which makes the valve open to remove the wind in the cuff.

The pump will automatically stop and the valve will open again. So the Arduino motor driver and valve subprogram are obtained as follows:

\begin{tabular}{l}
\hline void proses2() // dengan pompa otomatis \\
$\{$ if((millis() - refresh_time_data) > REFRESH_TIME_DATA) \\
\{ \\
tombolback(); \\
switch(status_ambil_data) \\
\{ \\
case 0: \\
\#if !MONITOR_OSCILOSCOP \\
sprintf(buf_tx, "Standby...p:\%4d", (int)p); // mengubah p ke \\
string yang disimpan di buf_tx. Misal p = 213, maka string \\
menjadi "standby...p:213" \\
Serial.printIn(buf_tx); \\
//Serial.printIn(buf_tx); \\
\#endif \\
valve_open(); \\
pompa_off(); \\
break; \\
case 1: \\
\#if !MONITOR_OSCILOSCOP \\
sprintf(buf_tx, "Memompa... p:\%4d", (int)p); // mengubah $p$ \\
ke string yang disimpan di buf_tx. Misal p=213, maka string \\
menjadi "memompa...p:213" \\
//Serial.println(buf_tx); \\
\#endif
\end{tabular}

pompa_on();

valve_close();

if $(d p>$ BATAS_MEMOMPA)

\{

delay (3000);

pompa_off();

status_ambil_data $=2 ; / / 100$;

for(int $\bar{i}=0 ; i<W I D E ; i++)$ array_dp $[i]=d p \_t e r f i l t e r$;

index_data $=0$; // index_data dibuat 0 


\section{DISCUSSION}

The pressure sensor has negative output and positive output. If the sensor is pressed, the negative output will decrease from the initial voltage and the positive output will increase from the initial voltage. the output of the pressure sensor will enter the buffer circuit and connect to the different amplifier circuit. Different amplifier if measured using an avometer of $0.32 \mathrm{~V}$ by setting it on multiturn. The output of different amplifiers is connected to the Arduino Mega on pin A0 and also to the filter circuit. The filter output is connected to the Mega Arduino on pin A1. Then the data will be processed to digital and the measurement results will be displayed on the LCD TFT.

\section{CONCLUSION}

After the data and analysis of measurements have been carried out, the writer can conclude that from the module test with digital blood pressure meter (tensimeter) in 5 respondents, it was produced that the systolic error rate was $0.08 \%$ and the diastolic error rate was $0.09 \%$. This module has a pump limit of up to $250 \mathrm{mmHg}$ because the cuff cannot be pumped again.

\section{REFERENCES}

[1] E. B. Nina Huwaida Zunnur, A. Ari Adrianto, "Digital Terhadap Pengukuran Tekanan Darah pada Usia Dewasa," vol. 6, no. 2, 2017.

[2] F. O. Indriani Lumantow, Sefti Rompas, "Hubungan Kualitas Tidur dengan Tekanan Darah pada Remaja di Desa Tombasian Atas," vol. 4, 2016.

[3] F. Haendra, D. Anggara, and N. Prayitno, "Faktor-Faktor Yang Berhubungan Dengan Tekanan Darah Di Puskesmas Telaga Murni," vol. 5, no. 1, 2013.

[4] Parlindungan Fernando Nainggolan; Harianto; Madha Christian Wibowo, "Journal of Control and Network Systems Data Tekanan Darah pada Mobile Platform Android," vol. 4, no. 1, 2015.

[5] Menteri Kesehatan, "Undang - Undang Republik Indonesia Nomor 11," 2017. 